\title{
English as a Lingua Franca from an applied linguistics perspective: In the context of Japan ${ }^{1}$
}

\author{
Nobuyuki HINO \\ Osaka University \\ Osaka, Japan
}

\begin{abstract}
For the past two decades, the concept of English as a Lingua Franca (ELF) has been a topic of much debate among researchers in the global use of English, including those involved in English language teaching (ELT). While in many respects ELF may be viewed just as a new name for its predecessors, such as World Englishes (WE) and English as an International Language (EIL), in other ways it also provides some fresh perspectives for the function of global Englishes. In particular, having grown chiefly out of Europe, where English has traditionally been studied as a foreign language rather than a second language, the ELF paradigm is often suited for the needs of learners of English in the Expanding Circle. With Japan as a primary example, the present paper discusses the significance of the concept of ELF and of the studies within its framework for ELT in the Expanding Circle. An important argument of this article is that studies in the early days of ELF, seeking for elements to facilitate international intelligibility, are still highly useful for ELT in the Expanding Circle. They cater especially to ELT in the Asian Expanding Circle, where pedagogical models are of crucial importance, no less than current ELF studies focusing on the fluid and translingual nature of ELF do. This paper points to the need for ELT teachers to be eclectic and integrative, learning from multiple paradigms, including ELF, WE, and EIL, while even going beyond the newness and oldness of pedagogical approaches, in order to best serve their students.
\end{abstract}

Keywords: ELF, English Language Teaching, English as a Lingua Franca, World Englishes, EIL, English as an International Language, ELT, Expanding Circle, Japanese English

\section{For citation:}

Hino, Nobuyuki. 2020. English as a Lingua Franca from an Applied Linguistics perspective: In the context of Japan. Russian Journal of Linguistics 24 (3). 633-648. DOI: 10.22363/26870088-2020-24-3-633-648

${ }^{1}$ An earlier working-paper version of the present article, here extensively revised and updated, appeared under the title "Significance of the concept of ELF for ELT pedagogy in Japan" in Hino, N. (ed.) (2015) Korekara no Eigokyoiku [English language teaching: Looking ahead], Graduate School of Language and Culture, Osaka University, 1-12, as a preliminary paper for the invited plenary panel "Globalized English: Transnational interactions" at the 2015 LTTC International Conference, National Taiwan University, Taipei, Taiwan, April 18-19, 2015. 
Научная статья

\title{
Английский язык как лингва франка в аспекте прикладной лингвистики: в контексте Японии
}

\author{
Нобуюки ХИНО \\ Осакский университет \\ Осака, Япония
}

\begin{abstract}
Аннотация
В последние два десятилетия концепт английского языка как лингва франка (ELF) стал темой многочисленных дискуссий среди тех, кто занимается проблемой глобального использования английского языка, в том числе тех, кто связан с преподаванием английского языка. Несмотря на то что по многим параметрам ELF можно рассматривать как новое наименование предыдущих концептов, таких как варианты английского языка в мире (World Englishes, или WE) и английский как международный язык (English as an International Language, или EIL), в некотором смысле этот термин раскрывает новые перспективы функционирования вариантов глобального английского языка. В частности, получив развитие преимущественно в Европе, где английский традиционно изучается как иностранный, а не второй язык, парадигма ELF часто соответствует потребностям изучающих английский язык в Расширяющемся круге. Взяв в качестве основного примера Японию, автор данной статьи обсуждает значимость концепта ELF и его изучения в рамках преподавания английского языка в Расширяющемся круге. Основная мысль данной статьи заключается в том, что самые первые исследования ELF, нацеленные на поиск того, что обеспечивает понимание в международном масштабе, до сих пор представляют большую ценность для преподавания английского языка в Расширяющемся круге. Особенно они ориентированы на азиатские варианты Расширяющегося круга, где решающую роль играют модели обучения, не меньше, чем современные исследования ELF, сфокусированные на гибкой транслингвальной сущности ELF. Статья подчеркивает необходимость требований эклектичности и интегративности в подходе к обучению английскому языку, преподаватели которого должны взять все полезное из теорий ELF, WE и EIL, выходя за рамки инноваций и традиций педагогических подходов, что будет весьма благотворно для студентов.
\end{abstract}

Ключевые слова: английский язык как лингва франка, варианты английского языка в мире, английский как международный язык, Расширяющийся круг, японский вариант английского языка, преподавание английского языка

\section{Для цитирования:}

Hino N. English as a Lingua Franca from an Applied Linguistics perspective: In the context of Japan. Russian Journal of Linguistics. 2020. Vol. 24. № 3. P. 633-648. DOI: 10.22363/26870088-2020-24-3-633-648

\section{Introduction}

The present paper discusses the concept of English as a Lingua Franca (ELF) from an applied linguistics perspective, with special attention to the significance of ELF from the viewpoint of English language teaching (ELT) for the Expanding Circle (Kachru 1985, Proshina 2019), where English has only limited functions domestically. In this undertaking, Japan is employed as a sample from the Expanding Circle. ELF is a relatively new school of thought that made a major debut with Jenkins (2000) and has been growing fast in the field of applied 
linguistics. In the latest development, Kecskes (2019) sheds new light on ELF from the perspective of pragmatics. As a study of global Englishes, the notion of ELF is preceded by more conventional paradigms with different orientations, most notably World Englishes (WE) (Kachru 1976, 1985, 1997) and English as an International Language (EIL) (Smith 1976, 1978, 1981).

The emergence of the ELF school has revitalized the study of Englishes for international communication in response to today's social needs, especially for the Expanding Circle, which has often been left behind in WE studies in its relative focus on the Outer Circle, where English has important intra-national functions. On the other hand, despite its short history of only two decades thus far, there have already been notable transitions in the focus of ELF studies. Pedagogical implications of those shifts will also be analyzed here.

\section{Transitions in the concept of ELF}

As mentioned above, there have already been some major transitions in the trend of ELF research. Preceding the latest focus on the multilingual or translingual nature of ELF, called the "ELF3" phase by Jenkins (2015), a shift of emphasis toward interactional dynamism ("ELF2") was a conspicuous change, as explained in this $>$.

The study of ELF started as a search for "core" elements that would make it possible for speakers of different varieties of English to understand each other: the "Lingua Franca Core" (LFC) proposed by Jenkins. Her studies at this stage (Jenkins 2000, 2002), now known as "ELF1," included the description of core and non-core features in the phonology of Englishes for international communication. ELF research in those days also triggered the expectation that the concept of the LFC might be applicable to some aspects other than pronunciation as well, such as lexicogrammar (Seidlhofer 2006).

Jenkins' research on English as an international language aroused much interest among ELT professionals across the world, perhaps with even a stronger impact than any of her predecessors in the study of global Englishes. It is also my view that Jenkins (2000) had the potential of bringing about significant advances in ELT pedagogy. However, her proposal met with criticisms not only by conservative linguistic purists but also by a lot of WE and EIL scholars who were supposed to share her philosophy of de-Anglo-Americanization of English, or the idea of liberating non-native speakers from native speaker norms.

This unfortunate discord was exhibited, among other instances, in a symposium "Perspectives on English as a Lingua Franca" at the 2007 conference of the International Association for World Englishes (IAWE) in Regensburg, Germany, whose panelists included two of the representative ELF scholars, Jennifer Jenkins and Barbara Seidlhofer, and some noted WE scholars. This panel discussion, held at the annual meeting of WE (and EIL) researchers, was a rare occasion for those both from WE and ELF camps to exchange their views at a major academic conference. However, what I witnessed was that the atmosphere created 
through the discourses at this symposium was not exactly friendly. Especially, some comments from the floor criticized the ELF position for attempting to prescribe and impose one monolithic variety of English (a cardinal sin for WE proponents in their quest for diversity), though this claim was refuted by Jenkins on the spot as a misunderstanding of the concept (cf. Jenkins 2009).

In fact, Jenkins had reiterated many times that ELF is for diversity (e.g. 2006, 2007), but WE scholars on the whole did not seem to be convinced. I basically agree with Jenkins that it is a sort of misunderstanding, though the notion of LFC is indeed often interpreted to aim for one uniform English.

Interest in the LFC has also gradually waned among ELF scholars themselves. While early ELF literature was filled with discussions of the LFC, current publications on ELF, including articles in the Journal of English as a Lingua Franca, only make sporadic mention of the concept. It was especially ironic that the fad had already passed when Robin Walker published a significant book in 2010 on an application of LFC to actual pedagogy, which turned out to exert only limited influence despite its usefulness. Though in my observation even ELF researchers generally fail to appreciate the true value of the LFC, this attitudinal change among ELF proponents is also a reflection of a shifting tide in human and social sciences, namely, a move toward constructivism (e.g., Kohn 2018).

The notion of constructivism, when used in language study, refers to a view that linguistic behaviors are constantly dependent on interactional dynamism, always occurring in a fluid manner in ever-changing situational contexts. In this line of thinking, presupposition of fixed and stable elements in communication is criticized for being "essentialistic." From the constructivist position of ELF researchers today, the concept of LFC seems to look too static to reflect the dynamic nature of actual ELF interaction. The emphasis on the fluidity of ELF interaction is most evident in an argument by a representative of the ELF school, Henry Widdowson (2015), that ELF should be viewed in terms of "variation" in contrast to WE studies that deal with the issues of "variety" (cf. Seidlhofer 2011).

\section{Pedagogical implications of ELF research: Past and present}

As presented in the previous section, the transitions that have taken place during the two decades of ELF studies can be summarized as a shift in focus from the LFC to interactional dynamism, with translingualism as the latest trend. This section will analyze pedagogical implications of both the early and later ELF studies, with more emphasis on the former, which tends to be neglected nowadays.

In academic research, when a theory is replaced by a newer version, the older one is often deemed useless. However, previous theories actually should be considered to retain their own worth and remain useful in certain contexts. In the field of language study, for instance, throughout the developmental process of Chomskyan linguistics since Chomsky (1957) to date, the model proposed in Chomsky (1965), known as the Standard Theory, is still the most usable if the purpose is direct application to pedagogical grammar in ELT, regardless of 
Chomsky's or other theoretical linguists' intentions. The paradigm of methodological analysis in ELT is another example. While the trinity of "approach, method, and technique" (Anthony 1963) seems to have been taken over by another analytical framework, "approach, design, and procedure" (Richards and Rodgers 1986), the former still serves better when the researcher wishes to separate the issues of teaching materials from methodological considerations. Likewise, early ELF studies, represented by Jenkins (2000), have pedagogical potential that later ELF research has come to de-emphasize without much further exploration.

\subsection{Significance of early ELF studies for ELT}

From pedagogical perspectives, Jenkins (2000) was significant at least on four counts. Below, each of those points will be discussed, especially with regard to their current relevance to the teaching of English in Japan.

\subsubsection{Issues of intelligibility revisited}

Firstly, Jenkins (2000) brought back the issue of phonological intelligibility across varieties of English. Since the classic study by Smith and Bisazza (1982), it has generally been assumed that understanding English with varieties of pronunciation is a matter of "getting used to," and that exposing learners to the diversity will solve the problem. However, Jenkins (2000) revealed that unintelligibility due to diversified phonology deserved more systematic treatment, as it could bring about serious difficulty in using English for international communication.

\subsubsection{Highlighting the importance of accommodation}

Secondly, Jenkins (2000) pointed to the importance of "accommodation" that had often been made light of in WE studies. With the strong emphasis on the value of diversity in the WE paradigm, a general assumption among WE proponents is that listeners and readers are primarily the ones who should make efforts to understand varieties of English (though usually restricted to Inner and Outer Circle varieties). In other words, there is some tendency among WE scholars to de-emphasize the need for accommodating one's language to the interlocutors' receptive repertoire. Highlighting the significance of accommodation remains one of the greatest contributions of Jenkins (2000) to the study of global Englishes to date.

\subsubsection{Upholding the legitimacy of Englishes from the Expanding Circle}

Thirdly, Jenkins (2000) was a gospel for users of English from the Expanding Circle. While the WE paradigm has been instrumental in improving the status of Englishes in the Outer Circle vis-à-vis those in the Inner Circle, WE scholars have traditionally been rather negative about extending the same privilege to their 
Expanding Circle counterparts. Historically, the WE school can be traced back to Halliday, McIntosh, and Strevens (1964), a group of leading UK linguists, who recognized the development of new varieties of English in former British territories, namely, the Outer Circle. Since then, postcolonial Englishes, or varieties in the Outer Circle, have been the primary concern for WE scholars. As a result, while liberating the Outer Circle from native speaker norms, the WE paradigm created a new discrimination between the Outer Circle and the Expanding Circle (Hino 2009a). On the other hand, Jenkins (2000) spoke for the rights of the Expanding Circle to employ their own models of English. Though Jenkins herself is from the U.K., it is no coincidence that many leading ELF scholars come from the Expanding Circle, including Barbara Seidlhofer (Austria) and Anna Mauranen (Finland). Drawing on the title of one of the Star Wars films, ELF may be characterized as "The Expanding Circle strikes back."

\subsubsection{Paving the way for new models of English through LFC}

Last but not least, though often interpreted otherwise, the LFC proposed by Jenkins $(2000,2002)$ helps to identify new pedagogical models of English as an alternative to the traditional target of Anglo-American English. While boosting international intelligibility with the use of core features, speakers of English for international communication, the majority of whom are non-native speakers, are allowed to express their own identities by exploiting non-core features, without always adhering to Anglophone norms.

It was unfortunate that many readers of early ELF research literature mistook the LFC as restrictive for non-native speakers of English. In my observation, the misunderstanding is caused by regarding core features as important items and noncore features as unimportant ones. Actually, non-core features are the most exciting part of LFC, which provide users of English with freedom of expression.

For example, stress-timed rhythm, which is characteristic of native speaker English, is classified as one of the non-core features (Jenkins 2000, 2002). This means that non-native speakers of English are free to use syllable-timed rhythm, a more natural rhythm for many of them, without impeding international intelligibility.

Though it is true that the LFC is not universal, as intelligibility depends on who the interlocutor is (i.e. "intelligible to whom?"), this concept has still opened up a possibility for new models of English, which can be particularly useful for traditionally underprivileged speakers of English from the Expanding Circle. However, as the notion of "model" itself has come to be de-emphasized with the rise of constructivism, subsequent ELF research has not fully explored this potential.

\subsection{Significance of present ELF studies for ELT}

Much of current ELF research, under the pervasive influence of constructivism, views ELF communication as dynamic and fluid (e.g., Seidlhofer 
2011, Jenkins with Cogo and Dewey 2011, Jenks 2014, Baker 2015, Rose and Galloway 2019). An implication of this position for ELT pedagogy is an emphasis on authentic interaction in ELF. That is, it is important for teachers to lead their students to participate in a community of ELF users so that they may learn to cope with dynamic and fluid ELF situations through such experiences. On the other hand, one problem with this educational philosophy is the difficulty of trying to set up authentic ELF environment in traditional ELT classrooms. This issue will be taken up again in the next section.

Another major feature of present ELF research is, as briefly mentioned earlier, an emphasis on the translingual nature of ELF (Cogo 2012, Jenkins 2015, Baker 2015). This stance works as an antithesis against conventional monolingualism in ELT, where the use of students' native languages has been discouraged, if not entirely forbidden. Such traditional insistence on monolingualism in language teaching has already been criticized by Cook (2010) and others, but recent studies on the translinguality of ELF have further enhanced the awareness that it is only natural for ELT classrooms to be bilingual or multilingual.

\section{ELF for the teaching of English in Japan}

Pedagogical implications of ELF studies for ELT in Japan, an Asian Expanding Circle country, are enormous. Of particular significance among them are the following.

\subsection{LFC for developing models of Japanese English}

While native-speakerism in ELT is prevalent in Japan, as in many other parts of the world (Houghton \& Rivers 2013, Houghton \& Hashimoto 2018), it has also been a long-cherished dream for the Japanese to enjoy an indigenous Japanese English that can adequately express themselves in international communication. Indeed, the philosophy dates far back to Saito (1928) who claimed that "the English of the Japanese must, in a certain sense, be Japanized" (preface). While such a Japanese wish has often been met with cold shoulders from WE scholars due to the Expanding Circle status of Japan (Hino 2012b), Jenkins' LFC, particularly its description of non-core features, has provided very useful clues about how to take a step forward toward the development of original pedagogical models ${ }^{2}$ of Japanese English. The following two sections present two examples.

\subsubsection{Features of connected speech as non-core items}

Studies of the LFC endorsed, with empirical evidence, an earlier observation by Hino $(1987,1989)$ that features of connected speech, such as linking and elision,

${ }^{2}$ In discussing this issue, I try to use the expression "models of Japanese English" where possible, with the plural form "models" because it is my standpoint that each teacher and each learner should be entitled to their own model. 
are often counter-productive with respect to intelligibility in international communication. Connected speech is typical of native speaker phonology, which also contributes to the formation of the stress-timed rhythm characteristic of AngloAmerican English. An implication of this fact is that models of pronunciation for Japanese English may employ syllable-timed rhythm ${ }^{3}$ with only minimal features of stress-timed connected speech (Hino 2009b, 2012a, cf. Kirkpatrick 2010). Such pronunciation also has the advantage of representing Japanese identity even when speaking English. This will be a drastic change in ELT as opposed to the traditional view that it is ideal for users of English to sound like native speakers.

Features of connected speech are excluded, in principle, from my pedagogical model of Japanese English (Hino 2010, 2012a). In addition to the intelligibility factor, one of the reasons for this practice is the fact that pronouncing English that way makes me feel as if I am trying to assimilate myself into AngloAmerican culture by giving up my "Japanese-ness." This attitudinal issue will be further discussed in the next section.

\subsubsection{Suggesting a need for going into the phonetic level}

The LFC can also be interpreted to suggest a need to include some allophonic differences into models of Japanese English. While American English has been employed as the model for ELT in the public school system in Japan, pronunciation for production has usually been taught at the phonemic level without going into phonetic considerations, as evident in the transcription of pronunciation in ELT textbooks approved by the Ministry of Education. This traditional policy is largely based on the idea of teaching pronunciation with phonemics, especially well-known for the concept of "minimal pair," where "distinctive features" are highlighted with a de-emphasis on "redundant features." This conventional practice has brought about the interesting consequence that ELT in Japan does not really lead students to pronounce English like native speakers, in spite of the American English model, as far as allophones are concerned.

This issue has long been a contentious point among Japanese applied linguists who are interested in the globalization of English. The following is an excerpt from a talk in 1985 between two leading Japanese scholars in the field, Ikuo Koike and Harumi Tanaka.

Koike: Some concrete standards would be necessary. For example, we should perhaps lead students to acquire pronunciation at the phonemic level rather than expect them to achieve it at the allophonic level....

Tanaka: I must disagree with you on your advice that pronunciation be taught at the phonemic rather than allophonic level. Supporting the teaching at the phonemic level means that pronunciation is considered fine as long as sounds that make differences in meaning can be distinguished.

\footnotetext{
${ }^{3}$ The present paper will not go into the distinction between "syllable-timed rhythm" and "mora-timed rhythm."
} 
However, some points are quite important even at the allophonic level, for instance, aspirated sounds of $[\mathrm{p}][\mathrm{t}][\mathrm{k}]^{4} \ldots$.

Koike: Such as the distinction between [ $\left.\mathrm{p}^{\mathrm{h}}\right]$ in "pit" and [p] in "top."

Tanaka: Right... (Tanaka \& Koike 1985: 8. In Japanese. Translation mine)

The aspiration of word-initial voiceless plosives that Tanaka and Koike are talking about is one of the core features listed in Jenkins (2000). It is remarkable that Tanaka, an EIL pioneer who had been showing interest in the problem of intelligibility across varieties of English since the late 1970s (Tanaka 1978, cf. Hino 2014), was arguing for the teaching of pronunciation at the phonetic level, 15 years before Jenkins did likewise in her data-based study.

However, this idea of going into the allophonic level continues to be controversial. Concerning the arguments put forth by Jenkins (2000) on issues such as allophonic vowel length besides that of aspiration, Paroo Nihalani, a noted linguist well known for his research in Indian English, offers his criticism based on experiences in the Commonwealth that "speakers of L2 varieties have been communicating fairly successfully without such allophonic features" (Nihalani 2010: 32). He further comments from the perspective of pronunciation as an identity marker, a viewpoint mentioned in 4.1.1 above, that "attitudinal studies undertaken in India, Malaysia, Nigeria and Singapore at the undergraduate level have clearly revealed resentment against the native-like use of allophonic variants" (Nihalani 2010: 32). Summarizing this position, he asserts that "national identity is characterized by the phonemic vowel system of the local variety" (Nihalani 2010: 33). Thus, Nihalani holds that requiring learners to adhere to native-like allophonic norms is problematic both in terms of intelligibility and identity.

In discussing the feasibility of Japanese English for international communication in Hino (1989), I mentioned the teaching of pronunciation at the phonemic level as one possible option, while I also expressed some reservation about this position by calling it "a rather rough argument" (Hino 1989: 8).

As far as the issue of aspiration of word-initial voiceless plosives is concerned, I basically support, as a pedagogical model of Japanese English, the one without aspiration. My stance is due to the same two reasons cited by Nihalani, intelligibility and identity (Hino 2010, 2012a), informed by my years of experience in using English in international settings, although Japan belongs to the Expanding Circle, unlike the countries in the Outer Circle that he cites.

As to the former factor, international intelligibility, I usually pronounce those sounds without aspiration (e.g. [pet] rather than [ $\left.\mathrm{p}^{\mathrm{h}} \mathrm{et}\right]$ ), and in my observation, just as in Nihalani's, it hardly hampers communication. While many of Jenkins' proposals on the LFC match my experiences in communicating with both native and non-native speakers, this item is one of the exceptions. Regarding the latter identity issue, again as pointed out by Nihalani, pronouncing stops with aspiration makes

\footnotetext{
${ }^{4}$ Although I follow the original transcription in this quotation, it would be more appropriate if
} these sounds were transcribed as $/ \mathrm{p} / / \mathrm{t} / \mathrm{k} /$ in this context. 
me feel like a parrot, merely mimicking someone else's pronunciation while surrendering my own identity (Hino 1987).

However, it must be made clear here that the model of Japanese English that I propose is just a suggested alternative, which should never be forcefully imposed on any learner. Any of my students certainly has every right to aim for native-like pronunciation if that is their wish.

In summing up, while even the conventional American-English-based ELT in Japanese schools generally had not dealt with pronunciation at the phonetic or allophonic level, Jenkins' LFC (2000, 2002) suggests, drawing on empirical data, that it may be necessary to go into the phonetic level for some sounds to ensure international intelligibility. This proposal is somewhat ironic in that it will partially result in promoting native-like pronunciation when Jenkins' fundamental philosophy entails freedom for non-native speakers to deviate from native speaker norms. However, in any case, it would be fair to say that Jenkins' LFC, though controversial, has shed valuable light on the issue of international intelligibility of Englishes, which helps us greatly in reexamining the teaching of pronunciation in ELT in Japan.

\subsection{The importance of engaging learners in authentic ELF interaction}

Today's ELF research puts great emphasis on the dynamic and fluid nature of ELF interaction. This aspect has been especially highlighted since the ELF2 phase of ELF studies, but the idea was already implied in the ELF1 phase, when Jenkins (2000) argued for the significance of accommodation, adjusting one's English so that they will be better understood by an interlocutor in ELF communication. Although all human interactions are dynamic and fluid, enormous diversity in the participants' backgrounds, coupled with a vast variety of situational contexts, makes these aspects particularly salient features of ELF communication. Besides accommodation, the importance of "negotiation of meaning" (e.g. Seidlhofer 2009), the construction of meaning through collaboration between interlocutors, is also underscored in ELF studies today, though to a somewhat lesser degree than the concept of accommodation.

Traditional CLT (Communicative Language Teaching) hardly meets this new educational demand from ELF perspectives. So-called communicative activities in CLT classrooms are too often artificial simulations, which are not effective enough to help students acquire interactive communication skills to cope with dynamic and fluid ELF situations, such as accommodation and negotiation of meaning.

An even bigger factor affecting ELT in many Expanding Circle countries is that the great majority of students share their first language (usually Japanese, in the case of Japan), which makes peer interaction simply unauthentic. Not only does this fact reduce students' motivation for engaging in classroom interaction, but also such an unauthentic setting can produce the kind of English that is intelligible only 
to compatriots, without a chance for the students to find out what sort of English will be actually understood by international interlocutors.

Therefore, from the viewpoint of current ELF studies, a major task for English language teachers is to provide their students with authentic ELF environments in classrooms. One solution for this difficult problem in the context of higher education is to exploit English-Medium Instruction (EMI) (Doiz, Lasagabaster \& Sierra 2013, Jenkins 2014) classes for learning ELF skills (Hino 2018a, 2018b, 2019). With the demand for globalization of higher education, a number of Japanese universities have recently been launching content courses taught in English both at the undergraduate and graduate level. In addition to local Japanese students, many of those EMI classes include international students from various countries, most of whom are non-native speakers of English. This is an authentic ELF environment with great potential as an opportunity for students to experience ELF interaction in person, whether it is a biology, engineering, economics, or any other course.

I am presently working on the development of a pedagogical approach for helping students to acquire ELF skills, mainly through reflective practice in my graduate EMI class. Partly by drawing on the concept of Content and Language Integrated Learning (CLIL), I have named the approach Content and English as a Lingua Franca Integrated Learning (CELFIL) (Hino 2015, 2017a, 2018a, 2019).

A technique that I have devised for CELFIL is what I call Observed Small Group Discussion (OSGD) (Hino 2017b, 2018a, 2019). A group of four students, constituting an authentic ELF environment in consisting of both international and Japanese students, discusses a given topic while being observed by all their other classmates. After that, the teacher leads a whole-class discussion in which observers and discussants share their reflections not only on the content of the small group discussion but also on the communication strategies employed there, such as clarification, confirmation, translanguaging, backchannel, and non-verbal cues. In the next class, observers and discussants change places, applying to their new roles the knowledge that they gained in the previous session. Thus, in OSGD, students learn collaborative meaning-making in ELF through the cycle of observation, reflection, and practice.

\subsection{Endorsing the use of Japanese in ELT}

The announcement by the Japanese Ministry of Education in 2008 that ELT classes in senior high school "should in principle be conducted in English" (translation mine) has caused controversies among ELT teachers as well as applied linguists across the nation. Japanese, the first language for the majority of students, has generally been used extensively in ELT in this country. This traditional linguacultural and educational practice, known as yakudoku or kundoku, dates back more than a thousand years to when the Japanese studied classical Chinese by translating it word-by-word into their native language (Hino 1988, 1992). 
As briefly discussed earlier in section 3.2, recent ELF studies have shown that translanguaging is a natural aspect of ELF, and that insisting on the monolingual use of English in ELF communication is groundless. Along the same line as Cook (2010), who raised awareness among ELT professionals in the positive role of translation in the classroom, those ELF3 studies may be interpreted to endorse the legitimacy of the use of Japanese in ELT. On the other hand, in the sociolinguistic context of Japan, caution should be also taken so that Japanese should not be overused in ELT classes. In fact, the aforementioned yakudoku/kundoku tradition is so powerful in this country that both teachers and learners are strongly tempted to use Japanese whenever possible even in ELT situations.

\section{Conclusion}

This paper has analyzed some pedagogical implications of the concept of ELF for the Expanding Circle, with Japan as an example, placing a relative emphasis on early ELF research represented by Jenkins (2000), whose true significance does not seem to be recognized even by ELF scholars.

Each of the three major schools of thought on the study of global Englishes, namely, EIL, WE, and ELF, have their own strengths and limitations. It is desirable for ELT professionals to learn from all of them, along with other relevant disciplines, in order to devise appropriate pedagogy that will best prepare students for intercultural communication in English.

\section{Acknowledgments}

This research has been partly supported by JSPS KAKENHI Grant Numbers JP24520700, JP15K02678, and JP18K00738.

(C) Nobuyuki Hino, 2020

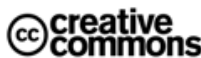

This work is licensed under a Creative Commons Attribution 4.0 International License https://creativecommons.org/licenses/by/4.0/

\section{REFERENCES}

Anthony, Edward M. 1963. Approach, method, and technique. English Language Teaching 17, 63-67.

Baker, Will. 2015. Culture and Identity through English as a Lingua Franca: Rethinking Concepts and Goals in Intercultural Communication. Berlin: De Gruyter Mouton.

Chomsky, Noam. 1957. Syntactic Structures. The Hague: Mouton.

Chomsky, Noam. 1965. Aspects of the Theory of Syntax. Cambridge, MA: The MIT Press.

Cogo, Alessia. 2012. ELF and super-diversity: A case study of ELF multilingual practices from a business context. Journal of English as a Lingua Franca 1 (2). 287-313.

Cook, Guy. 2010. Translation in Language Teaching: An Argument for Reassessment. Oxford: Oxford University Press. 
Doiz, Aintzane, David Lasagabaster \& Juan M. Sierra. 2013. Future challenges for Englishmedium instruction at the tertiary level. In Aintzane Doiz, David Lasagabaster, \& Juan M. Sierra (eds.), English-medium Instruction at Universities: Global Challenges, 213-221. Bristol: Multilingual Matters.

Halliday, Michael, Angus K. McIntosh \& Peter Strevens. 1964. The Linguistic Sciences and Language Teaching. Bloomington: Indiana University Press.

Hino, Nobuyuki. 1987. TOEFL de 650-ten: Watashi no eigoshugyo [650 on the TOEFL: My experiences in learning English]. Tokyo: Nan'undo.

Hino, Nobuyuki. 1988. Yakudoku: Japan's dominant tradition in foreign language learning. JALT Journal 10 (1\&2). 45-55.

Hino, Nobuyuki. 1989. Nihonshiki-eigo no kanosei [The possibility of Japanese English]. Modern English Teaching 26 (9). 8-9.

Hino, Nobuyuki. 1992. The yakudoku tradition of foreign language literacy in Japan. In F. Dubin \& N. A. Kuhlman (eds.), Cross-cultural Literacy: Global Perspectives on Reading and Writing, 99-111. Englewood Cliffs, NJ: Regents/Prentice Hall.

Hino, Nobuyuki. 2009a. WE in the Expanding Circle need our own models too!: Quest for equality in world Englishes. In Nobuyuki Hino (ed.), Eigo-kyoiku no atarashii riron to jissen [New Theories and Practices in English Language Teaching]. Osaka: Graduate School of Language and Culture, Osaka University. The Humanities and Social Studies in the Far East 32 (4). 2011. 256-260.

Hino, Nobuyuki. 2009b. The teaching of English as an international language in Japan: An answer to the dilemma of indigenous values and global needs in the Expanding Circle. AILA Review 22. 103-119.

Hino, Nobuyuki. 2010. Kokusaieigo toshiteno Japanese English no moderu no kochiku [Construction of models of Japanese English as EIL]. ELEC Bulletin 118. 37-42.

Hino, Nobuyuki. 2012a. Endonormative models of EIL for the Expanding Circle. In Aya Matsuda (ed.), Principles and Practices of Teaching English as an International Language, 28-43. Bristol: Multilingual Matters.

Hino, Nobuyuki. 2012b. Englishes in the Expanding Circle: Second-class citizens in the community of World Englishes? In Nobuyuki Hino (ed.), Eigo-kyoikuno aratanaru tenkai [New Developments in English Language Teaching], Graduate School of Language and Culture, Osaka University, 1-11. In T. Shiozawa, T. Enokizono, Y. Kurahashi, T. Komiya, \& M. Shimouchi (eds.). 2014. Gendaishakai to eigo: Eigo no tayosei o mitsumete [World Englishes in Changing Society], 140-152. Tokyo: Kinseido.

Hino, Nobuyuki. 2014. Review of the book World Englishes: Sekai no eigo eno shotai, eds. by H. Tanaka \& S. Tanaka. World Englishes 33 (2). 300-302.

Hino, Nobuyuki. 2015. Toward the development of CELFIL (Content and ELF integrated learning) for EMI classes in higher education in Japan. Waseda Working Papers in ELF 4. 187-198.

Hino, Nobuyuki. 2017a. Training graduate students in Japan to be EIL teachers. In Aya Matsuda (ed.), Preparing Teachers to Teach English as an International Language, 87-99. Bristol: Multilingual Matters.

Hino, Nobuyuki. 2017b. The significance of EMI for the learning of EIL in higher education: Four cases from Japan. In Ben Fenton-Smith, Pamela Humphreys \& Ian Walkinshaw (eds.), English as a Medium of Instruction in Higher Education in Asia-Pacific: From Policy to Pedagogy, 115-131. Cham, Switzerland: Springer.

Hino, Nobuyuki. 2018a. EIL Education for the Expanding Circle: A Japanese Model. London: Routledge. 
Hino, Nobuyuki. 2018b. Pedagogy for the post-native-speakerist teacher of English. In Stephanie Ann Houghton \& Kayoko Hashimoto (eds.), Towards Post-Native-Speakerism: Dynamics and Shifts, 217-233. Singapore: Springer.

Hino, Nobuyuki. 2019. Designing CELFIL (content and ELF integrated learning) for EMI classes in higher education in Japan. In Kumiko Murata (ed.), English-medium Instruction from an English as a Lingua Franca Perspective: Exploring the Higher Education Context, 219-238. London: Routledge.

Houghton, Stephanie A. \& Damian J. Rivers (eds.). 2013. Native-speakerism in Japan: Intergroup Dynamics in Foreign Language Education. Bristol: Multilingual Matters.

Houghton, Stephanie A. \& Kayoko Hashimoto (eds.). 2018. Towards Post-native-speakerism: Dynamics and Shifts. Singapore: Springer.

Jenkins, Jennifer. 2000. The Phonology of English as an International Language. Oxford: Oxford University Press.

Jenkins, Jennifer. 2002. A sociolinguistically based, empirically researched pronunciation syllabus for English as an International Language. Applied Linguistics 23 (1). 83-103.

Jenkins, Jennifer. 2006. Global intelligibility and local diversity: Possibility or paradox? In Rani Rubdy \& Mario Saraceni (eds.), English in the World: Global Rules, Global Roles, 32-39. London: Continuum.

Jenkins, Jennifer. 2007. English as a Lingua Franca: Attitude and Identity. Oxford: Oxford University Press.

Jenkins, Jennifer. 2009. English as a lingua franca: Interpretations and attitudes. World Englishes 28 (2). 200-207.

Jenkins, Jennifer. 2014. English as a Lingua Franca in the International University: The Politics of Academic English Language Policy. London: Routledge.

Jenkins, Jennifer. 2015. Repositioning English and multilingualism in English as a lingua franca. Englishes in Practice 2 (3). 49-85.

Jenkins, Jennifer, Alessia Cogo \& Martin Dewey. 2011. Review of developments in research into English as a lingua franca. Language Teaching 44 (3). 281-315.

Jenks, Christopher J. 2014. Social Interaction in Second Language Chat Rooms. Edinburgh: Edinburgh University Press.

Kachru, Braj. B. 1976. Models of English for the Third World: White man's linguistic burden or language pragmatics? TESOL Quarterly 10 (2). 221-239.

Kachru, Braj. B. 1985. Standards, codification and sociolinguistic realism: The English language in the Outer Circle. In Randolph Quirk \& H.G. Widdowson (eds.), English in the World: Teaching and Learning the Language and Literatures, 11-30. Cambridge: Cambridge University Press.

Kachru, Braj. B. 1997. World Englishes 2000: Resources for research and teaching. In Larry E. Smith \& Michael L. Forman (eds.), World Englishes 2000, 209-251. Honolulu: University of Hawaii Press.

Kecskes, Istvan. 2019. English as a Lingua Franca: The Pragmatic Perspective. Cambridge: Cambridge University Press.

Kirkpatrick, Andy. 2010. English as a Lingua Franca in ASEAN: A Multilingual Model. Hong Kong: Hong Kong University Press.

Kohn, Kurt. 2018. MY English: A social constructivist perspective on ELF. Journal of English as a Lingua Franca 7 (1). 1-24.

Nihalani, Paroo. 2010. Globalization and international intelligibility. In Mukul Saxena \& Tope Omoniyi (eds.), Contending with Globalization in World Englishes. Bristol: Multilingual Matters.

Proshina, Zoya G. 2019. Elaborating on the Expanding Circle. World Englishes 38 (1-2). 233-244. 
Richards, Jack C. \& Ted S. Rodgers. 1986. Approaches and Methods in Language Teaching. Cambridge: Cambridge University Press.

Rose, Heath \& Nicola Galloway. 2019. Global Englishes for Language Teaching. Cambridge: Cambridge University Press.

Saito, Hidezaburo. 1928. Saito's Japanese-English Dictionary. Tokyo: Nichieisha. (Reprinted in 2002. Tokyo: Nichigai Associates.)

Seidlhofer, Barbara. 2006. English as a Lingua Franca in the Expanding Circle: What it isn't. In Rani Rubdy \& Mario Saraceni (eds.), English in the World: Global Rules, Global Roles, 40-50. London: Continuum.

Seidlhofer, Barbara. 2009. Common ground and different realities: World Englishes and English as a Lingua Franca. World Englishes 28 (2). 236-245.

Seidlhofer, Barbara. 2011. Understanding English as a Lingua Franca. Oxford: Oxford University Press.

Smith, Larry E. 1976. English as an international auxiliary language. RELC Journal 7 (2). 38-53. In Larry E. Smith (ed.). 1983. Readings in English as an International Language, 1-5. Oxford: Pergamon Press.

Smith, Larry E. 1978. Some distinctive features of EIIL vs. ESOL in English language education. The Culture Learning Institute Report, June, 5-7 \& 10-11. In Larry E. Smith (ed.). 1983. Readings in English as an International Language, 13-20. Oxford: Pergamon Press.

Smith, Larry E. 1981. English as an international language: No room for linguistic chauvinism. Nagoya Gakuin Daigaku Gaikokugo Kyoiku Kiyo 3. 27-32. In Larry E. Smith (ed.). 1983. Readings in English as an International Language, 7-11. Oxford: Pergamon Press.

Smith, Larry E. \& John A. Bisazza. 1982. The comprehensibility of three varieties of English for college students in seven countries. Language Learning 32 (2). 259-269. In Larry E. Smith (ed.). 1983. Readings in English as an International Language, 59-67. Oxford: Pergamon Press.

Tanaka, Harumi. 1978. Eibeijin dakeno monodewa nai kokusaihojogo toshiteno eigo [English as an international auxiliary language not owned solely by Anglo-Americans]. The English Teachers' Magazine 26 (11). 64-67.

Tanaka, Harumi \& Ikuo Koike. 1985. Chukangengo to atarashii eigokyoikuron no kanosei [Interlanguage and possibility of a new paradigm of English language teaching]. ELEC Bulletin 84. 2-12.

Walker, Robin. 2010. Teaching the Pronunciation of English as a Lingua Franca. Oxford: Oxford University Press.

Widdowson, Henry. 2015. ELF and the pragmatics of language variation. Journal of English as a Lingua Franca 4 (2). 359-372.

\section{Article history:}

Received: 29 November 2019

Revised: 13 July 2020

Accepted: 15 July 2020

\section{История статьи:}

Дата поступления в редакцию: 29 ноября 2019

Дата принятия к печати: 15 июля 2020 


\section{Bionote:}

Nobuyuki HINO, Ph.D. is Professor, Graduate School of Language and Culture, Osaka University, Japan. He is a former director of the International Association for World Englishes as well as a former president of the Japanese Association for Asian Englishes, and currently serves on editorial/advisory boards for Routledge, Wiley, and Springer. His primary research interest is the teaching of EIL (English as an International Language) in the Expanding Circle. Along with numerous book chapters and journal articles, his recent single-authored book is EIL Education for the Expanding Circle: A Japanese Model (Routledge, 2018).

\section{Contact information:}

Graduate School of Language and Culture, Osaka University

1-8 Machikaneyama-cho, Toyonaka, Osaka 560-0043 Japan

e-mail: hino@lang.osaka-u.ac.jp

ORCID ID: 0000-0001-8761-6278

\section{Сведения об авторе:}

Нобуюки ХИНО, Ph.D., профессор, магистратура Школы языка и культуры Университета Осаки, Япония. Входил в исполком Международной ассоциации исследователей вариантов английского языка, является экс-президентом Японской ассоциации исследователей азиатских вариантов английского языка. В настоящее время входит в редколлегии издательств Routledge, Wiley и Springer. Oсновной научный интерес преподавание английского как международного языка в Расширяющемся круге. Автор многих статей и глав книг. Опубликовал книгу "EIL education for the Expanding Circle: A Japanese model” (Routledge, 2018).

\section{Контактная информация:}

Graduate School of Language and Culture, Osaka University 1-8 Machikaneyama-cho, Toyonaka, Osaka 560-0043 Japan e-mail: hino@lang.osaka-u.ac.jp ORCID ID: 0000-0001-8761-6278 